\section{Scientific journal}

\section{PHYSICAL AND MATHEMATICAL EDUCATION}

Has been issued since 2013.

Науковий журнал

ФІЗИКО-МАТЕМАТИЧНА ОСВІТА

Видається 32013.
ISSN 2413-158X (online)

ISSN 2413-1571 (print)

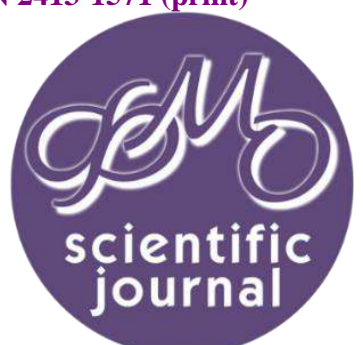

Школьний О.В., Захарійченко Ю.О. Методичні поради щодо підготовки до ЗНО з математики в сучасних умовах. Фізико-математична освіта. 2020. Випуск 3(25). Частина 1. С. 6-10.

Shkolnyi O., Zakhariichenko Yu. Methodological advices on preparation for EIA in mathematics in modern conditions. Physical and Mathematical Education. 2020. Issue 3(25). P. 6-10.

DOI 10.31110/2413-1571-2020-025-3-001

UDC 372.851

\author{
Oleksandr Shkolnyi \\ National Dragomanov Pedagogical University, Ukraine \\ shkolnyi@ukr.net \\ ORCID: 0000-0002-3131-1915 \\ Yurii Zakhariichenko \\ National University "Kyiv-Mohyla Academy", Ukraine \\ yzakhar@gmail.com \\ ORCID: 0000-0001-7436-3435
}

\title{
METHODOLOGICAL ADVICES ON PREPARATION FOR EIA IN MATHEMATICS IN MODERN CONDITIONS
}

Formulation of the problem. For more than a decade of active use, external independent assessment of academic achievement (EIA) from an experimental alternative to final and entrance exams has become one of the key national types of assessment, which performs both the functions of state final attestation for secondary school and the main tool for competitive selection to the country's universities. Thus, in modern conditions, the relevance of research on ways to improve the methodology of preparation for external assessment in mathematics is undeniable.

Materials and methods. To achieve the goals of the article, we use empirical methods: observation of the educational process of secondary school students and specially organized courses in preparation for the external examination in mathematics, as well as analysis of the results of their achievements. The study also used a set of scientific recognition methods: comparative analysis to clarify different views on the problem; systematization and generalization for the formulation of conclusions and methodological advices on preparation for national standardized assessments of educational achievements in mathematics; generalization of the author's pedagogical experience and observations.

Results. Since 2008, when the EIA in mathematics became the only possible form of entrance examination, it was extremely important for applicants not only to systematize knowledge of the school course of mathematics, but also to study the features of the form of representation of the test item. In particular, students were unfamiliar with the specifics of solving problems with alternatives, which were a significant part of the first tests of external assessment and were checked without human influence. In the first years of the introduction of EIA in mathematics, solving a large number of such problems allowed students to stop being afraid of them. But over time, as students in the school process began to constantly encounter these tasks, the negative side of excessive enthusiasm for them began to appear itself more and more. Nowadays, when solving a problem with alternatives, the students often tries not to reason, not to apply their knowledge, but are focused solely on getting the right answer. Thus, in the process of overemphasizing students' attention to the peculiarities of the forms of test tasks, the real aims of the process of preparation for testing in mathematics were replaced by erroneous ones. Indeed, instead of repeating and organizing the knowledge acquired by students during their studying in the school, the process of preparation for the external assessment began to reduce to teaching this student various methods of obtaining the correct answer. We suppose that such an approach to preparing for the EIA in mathematics is fundamentally wrong and offer readers 7 advices that will help to achieve the true goal of this type of assessment - to identify students' general and professional competencies, manifested through mathematical knowledge and ability to apply them in practice.

Conclusions. We express all the methodical advices given in the work from the point of view of the author's experience and cannot claim universality, but we consider it expedient to share our own achievements in this field and we will be glad when the described approaches agree with readers in their professional activity. We have implemented all these tips during the writing of a new manual for preparation to the external assessment in mathematics. We also sincerely hope that this manual will help students, independently or with the help of a teacher, to carry out a proper systematic repetition of the material of the school course of mathematics.

KEY WORDS: EIA in mathematics, SFA in mathematics modern conditions, methodical advices, senior school, educational achievements of students. 


\section{INTRODUCTION}

Formulation of the problem. External independent assessment of academic achievements (EIA) has now become a powerful tool for ensuring equal access to quality education for Ukrainian graduates. For more than a decade of active use, it has grown from an experimental alternative to final and entrance exams to one of the key national types of assessment, which performs both the functions of state final attestation for secondary school and the main tool for competitive selection for all universities in Ukraine.

It is clear that during its existence, the EIA has evolved in accordance with the changes that have taken place in Ukrainian society in general and in pedagogical science in particular. For testing in mathematics, these changes concerned, first of all, the content and forms of test tasks. In particular, the number of tasks for the application of mathematical knowledge in practice, in real life was grown. Also tasks for the application of abstract theories have become less technically cumbersome, without losing its mathematical sophistication and beauty. Due to these changes, the existing system of preparation for the external assessment in mathematics began to need to be reformed.

Analysis of current research. Currently, many well-known methodologists deal with the problems related to the process of preparation for the external examination in mathematics in Ukraine. Valentyna Bevz, Oksana Bukovska, Daryna Vasylieva, Albina Halperina, Oksana Yergina, Oleksandr Ister, Anatoliy Kapinosov, Vadym Karpik, Iryna Markova, Arkadii Merzliak, Yevhen Nelin, Dmytro Nomirovskyi, Oleksandr Repeta, Oleksii Tomashchuk, Mykhailo Yakir and others constantly publish their research in this direction (see, for instance, (Bevz, 2018), (Ister, 2019), (Kapinosov et al., 2019), (Rohanin, 2019), (Zakhariichenko et al., 2019a) etc).

For the last 15 years, our team of authors consisting of the authors of this article together with the PhD in Mathematics Liliana Zakhariichenko, a methodologist in mathematics at UTsOYaO, and Olena Shkolna, a mathematics teacher of the highest category at "Universum" lyceum (Kyiv), are actively working on methodological support for the process of preparation for independent assessment in mathematics. During this period, we have published more than 100 articles and textbooks on this topic. In particular, the monograph Shkolnyi 2015 is devoted to the theory and methodology of assessing the academic achievements of senior school students in Ukraine, and the most popular for us in preparing students for EIA in mathematics is a methodical set of manuals (Zakhariichenko et al., 2019b) and (Zakhariichenko et al., 2019c).

The purpose of this article is a theoretical rethinking of the goals, objectives and features of the EIA in mathematics in Ukraine and the formation of advices based on it to modernize the preparation of students for this type of testing in modern conditions.

\section{MATERIALS AND METHODS}

To achieve this aim we use the theoretical method of analysis of methodological literature on the research question. We also exploit some empirical methods: observation of the educational process of secondary school students and specially organized courses in preparation for external examinations in mathematics, as well as analysis of their achievements. In this article, as well, we use a set of methods of scientific knowledge: comparative analysis to clarify different views on the problem and determine areas of research; systematization and generalization for the formulation of conclusions and recommendations for the preparation of national standardized assessments of academic achievement in mathematics; generalization of the author's pedagogical experience and observations.

\section{RESULTS}

Since 2008, when external independent assessment in mathematics became the only possible form of entrance examination (see (Shkolnyi, 2015) and (Shvets et al., 2020)), it was extremely important for applicants not only to systematize knowledge of the school course of mathematics, but also to study a peculiarities of the test item representation form (with an alternatives (MCQ), with a short answer (SA), to establish correspondences (finding logical pairs) and with a full explanation). Detailed consideration of such features was natural, because traditionally in school for the assessment of students' academic achievements for a long time used only tasks with a full explanation, which were checked by teacher. Students were especially unfamiliar with the specifics of solving multiple choice and short answer problems, which were a significant part of the first tests of external assessment and were checked without human influence. Therefore, most of the first manuals for preparation for EIA focused on these forms of test tasks (see (Bohdanova, 2007), (Galperina, 2008) etc).

Using of problems with alternatives and short answers in the tests of external assessment in mathematics, apparently, was due to the lack of influence of the human factor on the results of their evaluation. In fact, when checking tasks with a full explanation, even with the correct answer, the teacher could lower the grade for that task based on his or her own subjective reasons. Even now, when checking open-ended tasks from the form B of the EIA test, ambiguities often arise, leading to differences of 1-2 points in the assessment of the 4-point task by the first and second check.

Consider as an example the 33rd task of the test of external examination in mathematics in 2020.

33. Let $f(x)=1$ and $g(x)=\sin x$. Perform tasks (1-3) in one figure.

1. Plot the function graph $f$.

2. Plot the function graph $g$ on the segment $\left[-\frac{\pi}{2} ; \frac{\pi}{2}\right]$.

3. Mark a point in the figure that is common to both constructed graphs of functions $f$ and $g$ and write its coordinates.

4. Find the set of all roots of the equation $f(x)=g(x)$ on the interval $(-\infty ;+\infty)$.

Even with carefully designed assessment schemes for this task, teachers had many problems during the check. For example, if one of the graphs of the functions is represented by a dotted line in the joint figure, can it be assumed that it is plotted correctly? There were no guidelines in the assessment schemes for this case, and this is natural, because it is impossible to predict in advance all possible options for student's solutions. But from this decision the fate of 2 points depended, because 1 point for 
the item $\mathbf{3}$ was credited only if both graphs of functions are correctly constructed and the coordinates of the point of their intersection in the explicit form are correctly founded and recorded.

It is clear that in the conditions of verification of standardized test, such controversial points are quickly agreed and a unanimous interpretation is adopted for all such works, as, in fact, was done in this case. However, imagine that there are not only 3 such tasks to check, but much more! Obviously, in this case it is much more difficult to avoid completely subjectivity during the assessment, due to the technical complexity of coordinating the actions of all checkpoints and all examiners. This is where the tasks with alternatives and short answers come to the rescue, which are checked by machine, and therefore, subjectivity in their evaluation is fundamentally impossible.

However, the tasks of these forms of representation have their own drawbacks. The main disadvantage of this is that when using such tasks, the teacher often cannot understand what the student who gave the wrong answer does not know. This, in turn, leads to a significant weakening of teacher-student feedback in the learning and preparation process, and thus to a deterioration in both the quality of the preparation process and the test results.

In the first years of the introduction of EIA in mathematics, solving a large number of problems with alternatives and short answers allowed students to get used to such problems, stop being afraid of them, and so on. But over time, when students in the process of learning at school constantly encounter these tasks in textbooks, dealing with tasks of such forms in the usual control work of different kinds, the negative side of excessive enthusiasm for them began to manifest itself more and more. The author's experience of preparation for EIA shows that now quite often during solving a problem with alternatives the student tries not to reason, not to apply their knowledge, for example, to build a mathematical model of a real situation, but focused solely on getting the right answer.

Various methods of guessing answers to test tasks, to which we drew readers' attention in our articles (see (Zakhariichenko, 2009) and (Shkolnyi, 2012)), have also become extremely widespread. Referring again to the EIA test in mathematics in 2020, we give task 7 as an example of the manifestation of such trends.

7. Solve the equation $x^{2}-4 x+3=0$.

\begin{tabular}{|c|c|c|c|c|}
\hline A & B & C & D & E \\
\hline$-4 ; 3$ & $1 ; 3$ & $-3 ;-1$ & $-2 ; 3$ & $-1 ; 4$ \\
\hline
\end{tabular}

Problem 7 is easier to solve by one of the known algorithms studied in school (by the formula of roots or using the theorem inverse to the theorem of $\mathrm{F}$. Viet), than to perform the substitution of the roots from the alternatives in a given equation, but we know many cases such way of "solving" this problem.

Thus, we can state that in the process of overemphasizing students' attention to the peculiarities of the forms of test tasks, the real aims of the process of preparation for testing in mathematics were replaced by erroneous ones. Indeed, instead of repeating and organizing the knowledge acquired by students during their studying in the school, the process of preparation for the external assessment began to reduce to teaching this student various methods of obtaining the correct answer and finding some "markers" that point to it. Some tutors have even begun to build the entire system of preparation for testing in this way. In particular, before solving each individual test task, they ask students: "What did the authors of the test task want to catch us here?" In our opinion, such an approach to the preparation for the external examination in mathematics is fundamentally wrong and puts, so to speak, upside down the very idea of independent assessment, which is to identify students' general and professional competencies manifested through mathematical knowledge and ability to apply them in real life practice.

How to overcome the inflections that have arisen and make the process of preparation for the external examination in mathematics appropriate and relevant to its goals? Of course, there is probably no single and well-defined way to achieve this aim. However, based on the author's experience, we can provide some methodological advices, which, in our opinion, will help ensure the quality of preparation for the EIA in mathematics in modern conditions.

Advice \#1. Whereas most of the test participants are already accustomed to the forms of test tasks representation, we propose to use for the systematization and repetition of the school course of mathematics only tasks with a full explanation. They allow the teacher to find out how well the student understands the essence of the data repeated and to find out what he or she does not understand if he or she cannot solve the problem. Moreover, even using traditional EIA preparation manuals, the teacher often uses the task of any form of presentation as a task with a full explanation, requiring the student not only to indicate the correct answer, but also the way in which he or she has received it. This is important, because quite often the correct answer can be obtained by accident, making a few mistakes that, so to speak, "compensate" each other. By conducting a mathematical dialogue between teacher and student in solving a problem, we demonstrate the beauty of mathematics, including its application in various fields of human activity. This is the way for creation of additional motivation for students.

Advice \#2. Since the EIA test in mathematics for the above reasons can not only contain problems with a full explanation, but still contains problems of various forms, it would be at least carelessly to completely ignore them. Although the features of each form of test tasks are considered during the learning process, they need some attention as well. In our opinion, it is best to do this at the end of each individual content block by conducting a thematic test, which contains tasks of all forms used in the independent assessment. It is also natural to consider the peculiarities of the forms of test tasks immediately before passing the test, solving the combined tests in the format of the EIA test, which awaits students in each specific academic year.

Advice \#3. In our textbooks on preparation for external assessment (see (Zakhariichenko et al., 2019b) and (Zakhariichenko et al., 2019c)) we divide the repetition course into 10 sections according to the main content lines of school mathematics. The titles of these sections are "Numbers and expressions", "Functions and their graphs", "Equations and systems of equations", "Inequalities and systems of inequalities", "Text problems", "Elements of mathematical analysis", "Geometry on the plane", "Geometry in the space", "Coordinates and vectors", "Elements of combinatorics and stochastics". Of course, there 
are other ways of such a division, but the way described above allows us to constantly repeat the previously studied material during the study of the next sections, and therefore, constantly keep students, so to speak, in tone. For example, the use of trigonometry is present in sections $1,2,3,4,6,7,8$ and 9, i.e. in almost all sections of the manual.

Advice \#4. At the beginning of the repetition of each of the sections, it is desirable to refresh the students' memory by the most important theoretical material, and it should be done briefly and taking into account their level of preparation. Indeed, individual formulas and facts are ancillary and rarely used in testing. This is especially true for geometric data, because it is so diverse that it is almost impossible to fully cover it during a time-limited course of preparation for external assessment. It is clear that certain additional facts can help to solve some test problems faster. For instance, if student know the formula $a^{2}+b^{2}=(a+b)^{2}-2 a b$, then he or she can significantly simplify solving process for the following problem: "Let $x_{1}$ and $x_{2}$ are the roots of the equation $x^{2}-5 x-1=0$. Find out the value of the expression $x_{1}^{2}+x_{2}^{2}$." However, it is obvious that this problem can be solved rather simply without using the mentioned formula. At the same time, excessive overloading of poorly prepared students with formulas can lead to fear in them both of a particular topic and of the whole test. Therefore, in this situation the teacher should rely on experience, intuition, as well as to show his or her pedagogical skills. For example, with some students, it is advisable to practice the skills at the beginning of the repetition of a certain section with the help of a system of oral exercises that the teacher has to create, taking into account the mathematical potential of the child.

Advice \#5. To implement the didactic principle of individualization of education (Vashchenko, 1997) during group work in preparation for the external examination in mathematics, we divide the training tasks into three parts according to the level of difficulty. The tasks of Part 1 roughly correspond to the initial and average level of mathematical training of the student, the tasks of Part 2 - sufficient, and the tasks of Part 3 - high. Having sets of tasks of different levels of complexity, it is easier to organize work in mixed groups. After reviewing the theoretical data and analyzing the simplest typical tasks that everyone needs, we can give students tasks for independent work that correspond to the level of their preparation and require extreme stress on their mental abilities. As is known (Krutetskiy, 1968), it is under such conditions we can obtain the progress in learning and developing abilities of the students.

Advice \#6. It is very convenient to put all training tasks in pairs. For example, task a) the student performs together with the teacher, and similar task b) is given to him to consolidate the acquired skills and abilities. For the relatively simple tasks of Part 1, intended for students with poor training, the tasks in pairs naturally choose the same level of difficulty, slightly changing the condition. This allows you to consolidate the ability to follow the example, repeating the basic theoretical data and working out algorithms for solving the simplest problems. Note that for very "weak" students should use not only pairs, but threes, fours and so on. Task b) for more complex problems from Part 2 and Part 3 should be more significantly different from task a) and be somewhat more difficult. Then for students with an average level of preparation, task a) can be performed together with the teacher, and task b) the student performs independently. For "strong" students we can immediately give a more complex task b) for their self-study, if necessary, making the necessary adjustments. With some students, it is enough to discuss the algorithm, the sequential steps of solving task a), after which they will perform task b) at home.

Advice \#7. The implementation of the didactic principle of clarity (Vashchenko, 1997), in our opinion, will contribute to the use of a large number of graphs, diagrams, drawings for problems etc. In order to save time on solving training tasks, it is also convenient to use geometric problems with ready-made drawings for them. This approach is natural, because the test notebook that students receive during the independent assessment in mathematics also contains many drawings. Adequate perception of graphical data is also extremely useful for the student who lives in a modern technological society, where this way of presenting data is becoming increasingly dominant.

\section{CONCLUSIONS}

We express all the methodical advices given in the work from the point of view of the author's experience and cannot claim universality. Of course, it is natural that each teacher must have his or her own unique methodology of preparation to the external examination in mathematics. However, we consider it expedient to share our own achievements in this field and we will be glad when the described approaches agree with readers in their professional activity.

Note also that we have implemented all these tips during writing of a new manual for preparation for the EIA in mathematics (Zakhariichenko, 2020), which we offer to the attention of all professionals working in this field. We sincerely hope that this manual will help students independently or with the help of a teacher to systematically repeat the material of the school course and properly prepare for the external examination in mathematics. We are always ready for constructive discussions in the field of organization and preparation for independent assessment and will be grateful to readers for comments or comments that can be sent directly to our e-mail addresses.

\section{References}

1. Bevz Valentyna G., Bukovska Oksana I. (2018). Matematyka. Testovi zavdannia u formati ZNO [Mathematics. Test tasks in EIA format]. Kyiv: Osvita. [in Ukrainian].

2. Bohdanova Liudmyla G., Kinashchuk Natalia L. (2007). Zovnishnie testuvannia. Matematyka. Trenuvalni vpravy [External testing. Mathematics. Training exercises]. Kharkiv: Himnaziya. [in Ukrainian].

3. Galperina Albina R., Mikheeva Olena Ya. (2008). Matematyka. Typovi testovi zavdannia [Mathematics. Typical test tasks]. Kharkiv: Fakt. [in Ukrainian].

4. Ister Oleksandr S. Matematyka. (2019). Kompleksna pidgotovka do ZNO ta DPA [Mathematics. Complex preparation to EIA and SFA]. Kyiv: Geneza. [in Ukrainian].

5. Kapinosov Anatolii M. et al. (2019). Matematyka. Zbirnyk testovyh zavdan dlia pidhotovky do ZNO [Mathematics. Collection of the tasks for preparing to EIA]. Ternopil: Pidruchnyky i posibnyky. [in Ukrainian]. 
6. Krutetskiy Vadim A. (1968). Psihologia matematicheskih sposobnostei shkolnikov [Psychology of schoolchildren mathematical abilities]. Moskow: Prosveshchenie. [in Russian].

7. Rohanin Oleksandr M., Nelin Yevhen P. (2019). Matematyka. Zbirnyk testovyh zavdan dlia pidhotovky do ZNO [Mathematics. Collection of the tasks for preparing to EIA]. Kharkiv: Vesna. [in Ukrainian].

8. Shkolnyi Oleksandr V. (2012). Problema zakhystu vid uhaduvannia testovyh zavdan DPA I ZNO z matematyky [The problem of protection against guessing test tasks of the SFA and EIA in mathematics]. Scientific journal of NPU named after M.P. Drahomanov. Series 3. Physics and mathematics in higher and secondary school: a collection of scientific works. Kyiv: National Drahomanov Pedagogical University Publishing House. 9. 148-163. [in Ukrainian].

9. Shkolnyi Oleksandr V. (2015). Osnovy teoriyi ta metodyky ociniuvannia navchal'nyh dosiahnen z matematyky uchniv starshoyi shkoly v Ukrayini [The basis of theory and methodology of educational achievements for senior school students in Ukraine]. Monograph. Kyiv: Dragomanov NPU Publishing. [in Ukrainian].

10. Shvets Vasyl O., Bevz Valentyna G., Shkolnyi Oleksandr V., Matiash Olha I. (2020). Ukraine: School Mathematics Education in the last thirty years. In A. Karp (Ed.), Eastern European Mathematics Education in the Decades of Change. Switzerland: Springer.

11. Vashchenko Hryhorii H. (1997). Zahalni metody navchannia [General methods of teaching]. Kyiv: Vseukrainske tovarystvo imeni Vashchenka. [in Ukrainian].

12. Zakhariihenko Yurii O., Shkolnyi Oleksandr V. (2009). Vhaduvannia vidpovidei do testovyh zavdan: mestectvo chy shakhraistvo? [Guessing answers to math test questions: art or fraud]. Mathematics at school. 11. 3-11. [in Ukrainian].

13. Zakhariichenko Yurii O., Repeta Victor K., Markova Iryna S., Karpik Vadym V. (2019). Matematyka. Trenazher [Mathematisc. Training kit]. Kyiv: Litera LTD. [in Ukrainian].

14. Zakhariichenko Yurii O., Shkolnyi Oleksandr V., Zakhariichenko Liliana I., Shkolna Olena V. (2019). Povnyi kurs matematyky v testah. Encyklopediya testovyh zavdan': U 2 ch. Ch. 1: Riznorivnevi zavdannia [Full course of math in tests. Encyclopedia of test items. In 2 parts. Part 1. Tasks of different levels]. 9-th edition. Kharkiv: Ranok. [in Ukrainian].

15. Zakhariihenko Yurii O., Shkolnyi Oleksandr V., Zakhariichenko Liliana I., Shkolna Olena V. (2019). Povnyi kurs matematyky v testah. Encyklopediya testovyh zavdan': U 2 ch. Ch. 2: Teoretychni vidomosti. Tematychni ta pidsumkovi testy [Full course of math in tests. Encyclopedia of test items. In 2 parts. Part 2. Theoretical information. Thematic and final tests]. 3-rd edition. Kharkiv: Ranok. [in Ukrainian].

16. Zakhariichenko Yurii O., Shkolnyi Oleksandr V., Zakhariichenko Liliana I., Shkolna Olena V. (2020). Suchasna pidhotovka do ZNO z matematyky [Modern preparation to EIA in mathematics]. Kamianets-Podilskyi: Aksioma. [in Ukrainian].

\section{МЕТОДИЧНІ ПОРАДИ ЩОДО ПІДГОТОВКИ ДО ЗНО З МАТЕМАТИКИ В СУЧАСНИХ УМОВАХ О.В. Школьний, Ю.О. Захарійченко}

нПУ імені М.П. Драгоманова, НаУКМА, Україна

Анотація.

Формулювання проблеми. За більш ніж десятиліття активного використання зовнішнє незалежне оцінювання навчальних досягнень (ЗНО) з експериментальної альтернативи випускним та вступним іспитам перетворилося на один із ключових загальнодержавних видів оцінювання, який виконує як функції державної підсумкової атестації за курс загальноосвітньої школи, так і функції основного інструменту для проведення конкурсного відбору до університетів країни. Отже, в сучасних умовах актуальність досліджень щодо способів удосконалення методики підготовки до зно з математики $\epsilon$ незаперечною.

Матеріали і методи. Для досягнення цілей статті ми застосовуємо емпіричні методи: спостереження за навчальним процесом учнів загальноосвітніх шкіл і спеціально організованих курсів по підготовці до зНО з математики, а також аналіз результатів їхніх досягнень. У дослідженні також використано комплекс методів наукового пізнання: порівняльний аналіз для з'ясування різних поглядів на проблему; систематизація та узагальнення для формулювання висновків і методичних порад щодо підготовки до загальнодержавних стандартизованих оцінювань навчальних досягнень з математики; узагальнення авторського педагогічного досвіду і спостережень.

Результати. Починаючи з 2008 року, коли ЗНО з математики стало єдино можливою форми вступного випробування, надзвичайно важливою для абітурієнтів була не лише систематизація знань зі шкільного курсу математики, а й вивчення особливостей форми подання тестового завдання. Особливо учні були мало знайомі зі специфікою розв'язування завдань із альтернативами, які складали значну частину перших тестів зНО і перевірялися без участі людини. У перші роки впровадження зНО з математики розв'язування великої кількості таких завдань дозволяло учням перестати їх боятися. Але з часом, коли учні в процесі навчання в школі почали постійно зустрічатися з цими завданнями, негативний бік надмірного захоплення ними почав проявлятися все більше. Зараз при розв'язуванні завдання з альтернативами учень досить часто намагається не проводити міркування, не застосовувати свої знання, а орієнтований виключно на отримання правильної відповіді. Таким чином, у процесі надмірного акцентування уваги учнів на особливостях форм тестових завдань відбулася підміна мети процесу підготовки до тестування з математики - замість повторення та впорядкування набутих учнем під час навчання в школі знань прочес підготовки до ЗнО почав зводитись до навчання цього учня різноманітним прийомам отримання правильної відповіді. Ми вважаємо, що подібний підхід до підготовки до ЗНО з математики є принципово хибним і пропонуємо увазі читачів 7 методичних порад, які сприятимуть досягненню справжньої мети цього виду оцінювання - виявленню в учнів срормованих загальних і фахових компетентностей, що проявляються через математичні знання та вміння застосовувати їх на практиці.

Висновки. Усі наведені в роботі методичні поради висловлені з позицій авторського досвіду і не можуть претендувати на універсальність, але ми вважаємо дочільним поділитися власними здобутками в цій сфері й будемо раді, коли описані підходи згодяться читачам у професійній діяльності. Усі перелічені поради реалізовано нами під час написання нового посібника з підготовки до зНО з математики. Ми щиро сподіваємось, що цей посібник допоможе учням самостійно чи з допомогою вчителя здійснити належне систематичне повторення матеріалу шкільного курсу математики.

Ключові слова: ЗНО з математики, ДПА з математики, сучасні умови, методичні поради, старша школа, навчальні досягнення учнів. 